\title{
Ethic Economics, Fair Economy, New Economy, Sustainability and other Related Disciplines
}

\author{
Bijan Bidabad \\ B.A., M.Sc., Ph.D., Post-Doc. \\ Professor \\ Economics and Chief Islamic Banking Advisor \\ Bank Melli, Iran \\ E-mail:bijan@bidabad.com
}

\begin{abstract}
Evolution of humankind in forming economic order of the society passed from caring only individual benefit to looking for social interests. This was what followed in the last millenniums. In this paper, we review this evolutionary process that starts from utilitarianism and reaches to ethical approach in defining human being behavior. It concludes that following what the divine prophets and messengers have understood and legislated are more appropriate for human well-being both in their materialistic and spiritual lives.
\end{abstract}

Keywords: Ethic Economics, Fair Economy, New Economy, Sustainable Development, Utilitarianism

\section{Introduction}

Divine prophets, theosophists, and theologians attempted to enact sharia laws in order to recognize what needs to be done in order to abandon overindulgence and abstinence. At any time, according to the time and place specific characteristics, they endeavored to legislate or endorse previous laws in order to adjust people's behavior in the society towards equilibrium. Whenever communities tended to such overindulgence and abstinence, they suffered from various inconveniences. Manifestations of such losses can be witnessed in all behaviors of individuals and communities. In the contemporary era, in accordance with the human body's requirements, the human being has considered originality principle of enjoyment as his main goal, which has been rooted in thousands of years ago. Divine messengers all tried to balance such overindulgent behaviors. Heavenly books, including Quran, Torah, Bible, and the texts from non-Abrahamic religions in east and west, all have indicated the struggles of divine messengers in this field.

Many of the discussions which are headlines of strategic policies today, had been under consideration at the thousands of years before, and prophets and divine theosophists have explained these teachings in the past. Sustainable development, which is one of the raised problems at the international community, and has been put forward in theoretical and modern form in the $20^{\text {th }}$ century, is in the domain of ethic economics. Movements such as "Anti-consumption", "Ecological economics", "Green Economics", and "Freeganism", "New Economy" and Fair Economy" in recent decades are also along in this direction.

\section{Utilitarianism}

The root of thoughts and behavioral modeling of a human being in neoclassical economics comes from the philosophy of "Hedonism school of thought" or "Utilitarianism" ${ }^{1}$. Since ancient Greece till now, hedonism has been described in several ways such as Aristippus individual hedonism, Epicure limited individual hedonism, Jeremy Bentham and John Stuart Mill hedonism in public utility, Adam Smith sentiment hedonism, and hedonism in activism by Bertrand Russell.

Socrates believed that human being is seeking pleasure and salvation, and has no other duty, but pleasure is not achieved through satisfaction and lust, whenever be prevented from bodily desires. Aristippus ${ }^{2}$ (435BC-366BC) in spite of Socrates, said human being should listen to her natural call, and find out if that work is welcomed by his nature or not. If it is welcomed, she should do it, and if it is not, she should stop it. In other words, if the work is mild to her nature and creates pleasure, it is good, and if it is rough and against individual nature, she should stop doing that.

Epicure (34IBC-27IBC) also put forward hedonism. He considered continued relaxation and comfort rather than short and lusty pleasure. He said a wise man prefers spiritual pleasure to material enjoyments. Principally, in spite of Aristippus theory, he has introduced wisdom and intellect in limiting pleasure, and confines it in the framework of wisdom. The result is that he introduces a life in which wisdom influences pleasure and mental pleasures are superior to bodily pleasures. In other words, he

\footnotetext{
I - http://www.utilitarianism.com/

2 - Aristippus was a disciple of Socrates and lived at the time of Plato (347-428 BC).
} 
asked for ethical pleasure.

Jeremy Bentham (I832-I848) and John Stuart Mill (I806-I873) put forward the school of public or, the social interest which considers social profit. They have replaced individual hedonism with public or social hedonism and have changed ethical action of individual enjoyment to social enjoyment. The legitimacy of action is implemented in enjoyment and salvation of the community and truthfulness of action is the result of it, not the cause of it, and if an individual tries for public benefit, his own benefit will also be achieved. Mill's formulated utilitarianism as the "greatest-happiness principle". It holds that one must always act so as to create the greatest happiness for the greatest number of people in society. Bentham treats all forms of happiness as equal, whereas Mill argues that intellectual and moral pleasures are superior to more physical forms of pleasure. Mill distinguishes between happiness and contentment, claiming that the former is of higher value than the latter.

The motivation for action in the school of sentimentalism is humanistic feelings, which persuaded him to do that work. Adam Smith (1723-1790) and Arthur Schopenhauer (I798-1857) and Auguste Comte (1798-I857) have described humanistic feelings as the cause and even the ultimate goal of the action. They say the work based upon "selfishness" is not ethical and only the work with humanistic goals is ethical, not with the aim of selfishness.

Bertrand Russell (I872-1970) put forward the coordination theory of individual benefits and public benefits. The top ethical items of his theory are: the establishment of coordination between the individual and public benefits ${ }^{3}$. He believes that if the action does not cause losses to others, we have no reason to condemn that action ${ }^{4}$.

Desires, wants, affection, love, hate, disgust and other similar terms in the concept of motivations and emotions (in psychology) describe faculties in the human being; some of which are attractive and others are repulsive. From theosophists' point of view, the faculties inside human beings are classified into two main groups of aphrodisiac (lust) and anger. The aphrodisiac (lust) power in a human being is the faculty which absorbs every mild to the human nature and the anger faculty which prevent every rough. Net of these two attractive and repulsive faculties in every dimension draws the equilibrium of human being behavior.

\section{Sustainable Development}

Squandering causes corruption of sources by destruction and abandonment because of "purchase greed" or "imitative consumption pattern", or "keeping up with Jones consumption pattern" or "consumptionism" 5 or "habitual consumption", this term has more meaning of wastage rather than consuming, because the obtained sources are unused. Squandering causes a part of resources - because of factors such as "purchasing greed", "imitation consumption", or "show off consumption" or "encouragement consumption" or "consumption oriented" or other similar things- become spoiled or become garbage, the consumer has to work more to compensate the wasted materials and lose his leisure time to satisfy this consumption phenomenon and actually, he is imaginarily satisfied. Altogether, squandering in a society will cause: more goods be consumed without increasing utility, less products are produced, more labor force and factors of production be used in production and demand for goods and factors of production and prices and wage increase, leisure time and efficiency and social welfare decrease. $^{6}$

Squandering in the meaning of extravagance can be clearly understood by this example: ${ }^{7}$ If animals were intelligent, they practiced a better life. In this connection, when microbes enter our body, they live in it, as we live on the earth and eat from our body, which is similar to earth for them. The coexistence of many bacteria and microbes with human beings' bodies is a proved medical proposition. The body tolerates them, and they nourish in the body and live together with a human being. That is to say, for example, many bacteria help in the digestive system to fermentation and digest food, and health, and even life of human being depends on their existence. But the microbes and bacteria overdo their works so that the body dies, and they die too. Their actions are similar to our actions. We say other creatures are not intellectuals, but we who are intellectual, should not do things to ruin our lives. The masters have commanded in all these subjects: "eat and drink, but don't waste because God doesn't like squanderers..." which means human being enjoys so much from God's blessing so that he spoils his own life; that is why it is commanded not to squander...

\footnotetext{
3 - Bertrand Russell Speaks His Mind, 1960, Farsi translation, Amirkabir Publishing, I345, Tehran, pp 64-65.

4 - Bertrand Russell Speaks His Mind, 1960, Farsi translation, Amirkabir Publishing, I345, Tehran, p 68. science to force human being to more and more consumption of goods.

${ }^{6}$ - Bijan Bidabad, Squandering in Ethic Economics (Consumer and Producer Behaviors Analysis). 2010.

http://www.bidabad.com/doc/esraf-eghtesade-akhlagh-en.pdf

Bijan Bidabad, Overconsumption in Ethic Economics and Sustainable Development. 2010.

http://www.bidabad.com/doc/toseeh-payedar-eghtesade-akhlagh-en.pdf

7 - Speech of his Excellency Dr. hajj Nour-Ali Tabandeh Majzoubalishah, March 25 2008.

http://mazaresoltani.net/download/mp3/87/87-0I-25-sobhe-eshanbeh-aghl.mp3
}

5 - Samuel Strauss (I870-I953) Critics on Consumptionism. The Atlantic Monthly, November 1924. He defines consumptionism as the 
Hansa $^{8}$ believes that sustainable development is a process which covers all directions of human life affecting his livelihood. The meaning of "Green development" is quite different from sustainable development. Those who are in favor of green development prefer sustainability of environment to economic, social, and cultural considerations which are unidirectional consideration of the sustainable development goal along with the future life of the earth planet. Anyhow, in spite of views of various schools of thoughts" about sustainable development, especially in relationship with "Anthropocentrism", and "Ecocentrism”, United Nations Division for Sustainable Development ${ }^{10}$ has considered specific fields in the domain of sustainable development. ${ }^{\text {II }}$

Overconsumption is not only disagreeable, but also can be entered in the definitional domain of crimes. This is because overconsumer endangers other's interests to obtain his own interests; therefore, it should be principally defined as a crime. Certainly, crime is not a fixed rule with unchangeable meaning, and it is not considered crime before being legislated by criminal law. In sociologists' viewpoints, crime is an action which is against the society's interests, whether is considered by lawmakers or not ${ }^{\mathrm{I2}}$. Therefore, in law philosophy, in the definition of law it is said that it is a regulation governing people living in the society and if people live alone and out of society, they have no obligations and rights. The difference between law and ethics is that ethics are regarded and judged by people themselves, but in law point of view, goodness and badness are studied by the relationship with the others ${ }^{13}$.

\section{New Economy}

The new economy ${ }^{14}$ was a consequence of the dot-com bubble ${ }^{15}$ in the late 1990 s that shifted physical manufacturing-based production manner to a service-based economy. During this period, high growth and employment and low inflation rates caused the firms to be over-optimist to the future businesses and finally blemished business plans and the firms to fall into recession. Some economists knew this phenomenon as flourishing computer age and recited the problem as a result of negative effects of computer development and investment in information and communication technology that put the economy in the downward path of Kondratiev cycle. ${ }^{16}$

\section{Fair Economy}

Fair Economy was actually a behavioral reflection on the actual results of New Economy consequences in the early 2000s. Back of the mind of those who started to assert the New Economy regarded to find a solution to control the over-doing of human beings than what they actually need to be survived and happy. Economist of New Economy found that after I920s crises, the over-indulgence caused the subsequent Kondratiev cycle crisis to happen in 2000s. In this regard, many social and political structures of the domestic society and also the international community were scrutinized as the sources of flaws. Many movements were formed and each of them started to criticize some sides of the economy, politic, society in different fields of banking and finance, community currencies, jobs, local and macroeconomics, monetary and fiscal policies, social return on investment, environment, energy, climate change, industries and industrial strategy, international development, infrastructure, food, justice, democracy, political participation, inequality, poverty, public services, health and social insurance, wellbeing and work and leisure, immigration, sustainable growth, knowledge economy, governance, consumption and production, biodiversity and natural resources and etc. to build a fair economy. The main pivot of these topics is based on Sustainability, equity, equality in justice, efficient public sector, and so on.

As a result, all these movements emphasized that if lessons of ethic economics in forming suitable economic pattern is strengthened, we can guide economic behaviors towards moderate consumption and production behaviors. Moreover, if ethic teachings do not carry out this process, people will become instruments for production and consumption. And in the course of development of humanities, human beings will not reach to what he has been created for which is much valuable than material production and consumption. In other words, if the economic behavior of people were not trained, the traditional economy will pull people towards changing them into a machine for "just production-just consumption". That is to say; it is necessary to leave

\footnotetext{
8 - Hasna, A.M., 2007, Dimensions of sustainability, Journal of Engineering for Sustainable Development: Energy Environment and Health 2 (I):47-57 retrieved on 2008-04-20.

9 - Center for Sustainable Global Enterprise, Cornell University. Erb Institute for Global Enterprise, University of Michigan.

${ }^{10}$ - United Nations division for Sustainable Development. Documents: Sustainable Development Issues. Retrieved 2007-05-I2.

${ }^{11}$ - Bijan Bidabad, Global phenomenon of hunger and food squandering. http://www.bidabad.com/doc/Global-hunger-en.pdf

${ }^{12}$ - See: Public punishment jurisprudence. Motamed, Mohammad Ali, Tehran University Publication, Vol. I, P. I25, I973.

${ }^{13}$ - See: The philosophy of law. Katouzian, Naser. Publication Company Ltd,, Vol. I, pp. 540-54I, 1998.

${ }^{14}$ - Gordon, Robert J. (2000), "Does the 'New Economy' Measure up to the Great Inventions of the Past?" The Journal of Economic

Perspectives, v. I4, pp. 49-74.

I5 - Laffey, D. (2006). The Rise and Fall of the Dot Com Enterprises. Burke, A., ed. Modern Perspectives on Entrepreneurship. Ireland: Senate Hall Academic Publishing.

${ }^{16}$ - Gordon, Robert J. (2000) Interpreting the 'One Big Wave' in U.S. Long-term Productivity growth. Productivity, Technology and Economic Growth, v. I.
} 
some time for thinking and self-calculating, soul-purification, self-training, and spiritual and ethical affairs so that in this relation finds the purpose of her creation and steps forward towards spiritual elevation.

\section{Ethic Economics}

Ethic economics is a new name for the old value discussions in economics which analyze the economy and economic behaviors by observing ethical principles. It considers materialistic economic problems as well as value-based principles of human ethics. It studies both materialistic and spiritual dimensions of human being in relation to economics simultaneously and takes the human behavior into account from these two views, which in contrary to the materialistic view, it has a wider view and in addition to observing economic scientific rules, tries to find material and spiritual welfare of human beings in a broader range than just materials. ${ }^{17}$

In terms of neoclassical economics, a happy person is the one who consumes more, and it is synonymous with this matter that human being expends all his forces to produce goods and then, to consume them. But the ethic economics addresses a paradigm that whether the human being has been created for such a purpose or not. This subject is debated that whether if the teachings, which are derived from religion and disseminated in the economy and constitute the "ethic economics", can result in modifying the disposition of the society and diminishing many detriments of economic activities, and whether they can direct economic gluttonous and abatement towards an economic balance.

Peace and transcendence, elevation, humanity, non-materialistic love, spiritualities, altruism, worship, self- sacrifice, indulgence, sincerity... dimensions are not denied in neoclassic view, but are not considered. In other words, the characteristics of human behavior can be introduced into the economic behavior of the neoclassic theory, which had not been implemented before. Although it is said that economics is a material and non-spiritual subject; but ethic economics is looking for to consider all material economic discussions for the material and spiritual elevation of human beings simultaneously; and not just her material comfort.

Intents of people in the society are shaped inside each individual. These intents create the dispositions of people that form the "disposition of society". Disposition of society is known as the norms. If the disposition of society would be limited by legislation, the intents will be practically changed. This would be the basis of social reform through legislation. Undoubtedly, inducing of a thought or a method does not cause its implementation straightaway, but it is as quoted by His Honorable Majzoub-Ali-Shah": "Persistence of an idea or a method can be secured through customs and habits that are founded in the society". Thus, to change the disposition of society, it should be attempted to institutionalize the correct way in the people's lifestyle and habits by using educational teachings. This subject brings the discussion into the realm of morality and ethical education. ${ }^{19}$

With regard to ethical edification and human faculties, it has been quoted by His Honorable Sultan Hussein Tabandeh ${ }^{20}$ that ethical edification discusses about human moralities, which have been stabilized in his character and are dominant on his faculties, and his actions come from them. These moralities are divided into two groups: natural ones, which are unchangeable and very scarce; some people possess this kind of moralities. The second group is normal, which is known as adventitious. This group can be changed through habits and practice and by communication and speaking.

On the other hand, as ethics scholars have stated, the human temper does not become satisfied by achieving interes ts, and since it persistently tends to catch more pleasures, it needs to absorb more, and therefore, the avidity will increase. It has been expressed that $^{21}$ : "carnality will increase, if it is repressed". Therefore, reaching more satisfaction depends on more consumption and on moving towards the aforesaid intermediate goals.

Here we name some of the qualities of human beings in relation to her economic behavior; some of them are agreeable some are disagreeable, but the optimum behavior from the ethic economics point of view is moderation and balance between them. Overindulgence and under-indulgence locate at both sides of moderation and the most important economic behaviors locate under the topics of squandering, thriftiness, and moderation. Over-consumption and stinginess are also two extremes, and moderation in spending is between the two. Hoarding (accumulating wealth, gold and treasure) is the opposite of extravagance,

\footnotetext{
${ }^{17}$ - Bijan Bidabad, Equilibrium in ethic economics. 20I0. http://www.bidabad.com/doc/taadol-eghtesade-akhlagh-en.pdf

18 - Haj Dr. Noor-ali Tabandeh Majzoob-Ali-Shah, lecture on April 25, 2008, regarding profusion and disposition. http://mazaresoltani.net/download/mp3/87/87-02-05-sobhe-panjshanbeh-elm-va-esraf-kardan.mp3

${ }^{19}$ - Bijan Bidabad, Mahshid Sherafati, Disposition (Shakilah) of Society and Ethic Economics. 2014.

http://www.bidabad.com/doc/shakeleh-ejtema-eghtesade-akhlagh-en

20 - His Honorable Haj Soltan Hussein Tabandeh Reza-Ali-Shah the II, Manifestation of Trueness in Mysteries of Karbala Disaster,

Haghighat publication, Chapter I2.

${ }^{21}$ - His Honorable, Haj Sheikh Mohammad Hassan Salih-Ali-Shah, Pande Salih (Salih Advise). Haqiqat publication, I393. I5 ${ }^{\text {th }}$ print 2014.
} 
and moderation with traditional economic meaning (the science of subsistence) is in between them. Proudness, because of assets is overindulgence and carelessness to keeping wealth and assets up under-indulgence and keeping up the properties is the moderation. Financial circumspect and pass-out are two sides of overindulgence and under-indulgence and leaving the wishes and confronting with reality is the moderation. Amplifying the assets is overindulgence, and its opposite is wasting the properties is under-indulgence and balanced growth of wealth is moderation. Subsistence moderation is between wealth and poverty, and greed, covetousness, avarice, avidity, and cupidity are at overindulgence extreme and carelessness and negligence are at the opposite extreme as under-indulgence; and their moderation is contentment. Lavishness is opposite to abstinence and monastic, and caring the vale according to needs is at their moderation. Hardworking is the opposite of laziness and working, and the balance between them, is moderation. Jealousy and regret to others are two extremes and emulation and warning is moderation. Luxury and loving ornaments are opposites of rags clothed and cleanliness is the moderation. Thriftiness, meanness, miserliness, sordidness and vileness are at one side and wasting and throwing away and garbaging are the opposite side and consuming enough and safeguarding property is its moderation. Optimism and pessimism are the two extremes which are on the two sides of confidence. Cheating and being cheated are to extremes of transaction. Many other good qualities such as nourishing the poor, self-sacrifice, charity payment, generosity, honoring, safe custody, sociability, gentlemanly, giving generously, removing poverty, and ... are on the opposite side of disagreeable actions such as shortchanging, overcharging, self-interest, cheating, speculating, deception, fraud and dishonesty, and...

All these considerations have been neglected in neoclassic economics; therefore, mathematically speaking, the optimal in neoclassical economics is a local optimum, not a global one. Therefore, the concept of equilibrium (or moderation) in addition to material characteristics which we discussed, should include equilibrium characteristics, meaning being at the middle and justice (meaning: "putting thing at its right position") and if we add the goal of transcendence of human being spirit, the meaning of equilibrium in ethic economics is to put things in their right positions and achieve maximum growth and elevation of human being or the fulfillment of human being perfection. Putting things in their right positions mathematically means optimized use of them. Fulfillment of perfection means to make human being innate power practiced. Certainly, this growth and elevation is material as well as spiritual. That is to say; resources should be used for maximizing utilization (utility/production) in a way which in addition to satisfying material needs of human being, create the background for maximizing mental and spiritual growth and elevation of the human being as well.

\section{References}

His Honorable Dr. hajj Nour-Ali Tabandeh Majzoubalishah, (March 25 ${ }^{\text {th }}$ 2008). http://mazaresoltani.net/download/mp3/87/87-0I-25-sobhe-eshanbeh-aghl.mp3

His Honorable Haj Dr. Noor-ali Tabandeh Majzoob-Ali-Shah, lecture, regarding profusion and disposition (April 25, 2008) http://mazaresoltani.net/download/mp3/87/87-02-05-sobhe-panjshanbeh-elm-va-esraf-kardan.mp3

His Honorable Haj Sheikh Mohammad Hassan Salih-Ali-Shah, (I393H) Pande Salih (Salih Advise). Haqiqat publication. I5 ${ }^{\text {th }}$ print 2014.

His Honorable Haj Sultan Hussein Tabandeh Reza-Ali-Shah the II (I348H), Manifestation of Trueness in Mysteries of Karbala Disaster, Haghighat publication.

Bertrand Russell Speaks His Mind, (1960) Farsi translation, Amirkabir Publishing, I345H, Tehran.

Bijan Bidabad (2010) Equilibrium in ethic economics. http://www.bidabad.com/doc/taadol-eghtesade-akhlagh-en.pdf

Bijan Bidabad (2010) Overconsumption in Ethic Economics and Sustainable Development. http://www.bidabad.com/doc/toseeh-payedar-eghtesade-akhlagh-en.pdf

Bijan Bidabad, (2010) Squandering in Ethic Economics (Consumer and Producer Behaviors Analysis). http://www.bidabad.com/doc/esraf-eghtesade-akhlagh-en.pdf

Bijan Bidabad, Global phenomenon of hunger and food squandering. http://www.bidabad.com/doc/Global-hunger-en.pdf

Bijan Bidabad, Mahshid Sherafati (20I4) Disposition (Shakilah) of Society and Ethic Economics. http://www.bidabad.com/doc/shakeleh-ejtema-eghtesade-akhlagh-en

Center for Sustainable Global Enterprise, Cornell University. Erb Institute for Global Enterprise, University of Michigan.

Gordon, Robert J. (2000) Does the 'New Economy' Measure up to the Great Inventions of the Past? The Journal of Economic Perspectives, V. I4, pp. 49-74.

Gordon, Robert J. (2000) Interpreting the 'One Big Wave' in U.S. Long-term Productivity growth. Productivity, Technology, and Economic Growth, V. I.

Hasna, A.M., (2007) Dimensions of sustainability, Journal of Engineering for Sustainable Development: Energy Environment and Health 2 (I):47-57 retrieved on 2008-04-20.

http://www.utilitarianism.com/

Katouzian, Naser. (1998) The philosophy of law. Publication Company Ltd.

Laffey, D. (2006). The Rise and Fall of the Dot Com Enterprises. Burke, A., ed. Modern Perspectives on Entrepreneurship.

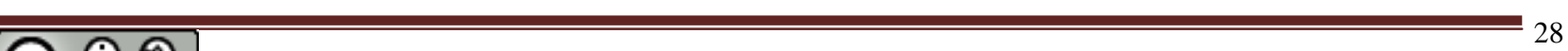


Ireland: Senate Hall Academic Publishing.

Motamed, Mohammad Ali, (1973) Public punishment jurisprudence. Tehran University Publication.

Samuel Strauss Critics on Consumptionism. (1924) The Atlantic Monthly, November.

United Nations Division for Sustainable Development. Documents: Sustainable Development Issues. Retrieved 2007-05-I2.

\section{Copyrights}

Copyright for this article is retained by the author(s), with first publication rights granted to the journal. This is an open-access article distributed under the terms and conditions of the Creative Commons Attribution license (http://creativecommons.org/licenses/by/4.0/). 